\title{
ANALYSIS OF ECO-INNOVATION FROM A BUSINESS PERSPECTIVE
}

\section{ANÁLISE DA ECOINOVAÇÃO DE UMA PERSPECTIVA DE NEGÓCIOS}

\author{
Paulo Mantelatto Pecorari E-mail: pmpecorari@gmail.com \\ Carlos Roberto Camello Lima* E-mail: ccamellolima@gmail.com \\ *Universidade Metodista de Piracicaba (UNIMEP), Piracicaba, SP
}

\begin{abstract}
Corporate challenges imposed by global economic competitiveness, coupled with addressing social inequalities and environmental problems, have been growing and becoming increasingly a silent form of selection in the business environment. In this sense, an evolution of society awareness and public governments, to a notion change, with regard to social behavior, mainly oriented to consumption form, has led companies to rethink the way in which they develop their new products. From this interaction between the companies' search for innovation and the worldwide need to be fit for the triple bottom line, Eco-innovation arises. The objective of this work is to evaluate what has been studied and applied on eco-innovation, analyzing some of works carried out between 2011 and 2015. This work has an exploratory character, through literature review, focused on a specific theme, with a structure of keyword-driven search. Through the results found, the work concludes that, eco-innovations must be financially viable, have their guidelines aimed at the performance of the business and be motivated by the knowledge that managers involved in the project should have about the company, with its vision based and oriented on avaliable resources.
\end{abstract}

Keywords: Environmental innovation, Eco-innovation, Literature review, Business.

Resumo: Os desafios corporativos impostos pela competitividade econômica global, somados ao enfrentamento das desigualdades sociais e dos problemas ambientais, vêm crescendo e se tornando cada vez mais uma forma silenciosa de seleção no ambiente de negócios. Nesse sentido, uma evolução da consciência da sociedade e dos governos para uma mudança de noção, no que se refere ao comportamento social, principalmente voltado para a forma de consumo, tem levado as empresas a repensar a forma como desenvolvem seus novos produtos. Dessa interação entre a busca das empresas por inovação e a necessidade mundial de adequação ao "triple bottom line" surge a Ecoinovação. O objetivo deste trabalho é avaliar o que tem sido estudado e aplicado em Ecoinovação, analisando alguns trabalhos realizados entre 2011 e 2015. Este trabalho tem um caráter exploratório, por meio de revisão bibliográfica, com foco em um tema específico, com estrutura de pesquisa baseada em palavras-chave. Por meio dos resultados encontrados, o trabalho conclui que as ecoinovações devem ser financeiramente viáveis, ter suas diretrizes voltadas para o desempenho do negócio e ser motivadas pelo conhecimento que os gestores envolvidos no projeto devem ter sobre a empresa, com sua visão pautada e orientada sobre os recursos disponíveis.

Palavras-chave: Inovação ambiental. Ecoinovação. Revisão da literatura. Negócios.

\section{INTRODUCTION}

The challenges encountered by companies, imposed by global economic competitiveness, coupled with addressing social inequalities and environmental problems, have been growing and becoming more and more a silent form of selection in 
the business environment. In this sense, the evolution of society awareness and public bodies, by the need for change, with regard to social behavior, mainly oriented to the form of consumption, has led companies to rethink the way in which they develop their new products.

This awareness can produce innovative responses to leverage sustainable development. The sustainable development can be understood based on the triple bottom line, that is, it must be directed by the integration between the economic, social and environmental performances (BAUMGARTNER; EBNER, 2010; VERGHESE; LEWIS, 2007). Historically, environmental protection was not part of the economic development agenda. Technological innovation has boosted this development and can now change this paradigm to be a way of alleviating the problem that economic development imposes on the environment.

It is in this context that eco-innovation emerged, a prerequisite for sustainable development. The European Commission Eco-Innovation Action Plan 2012 defined eco-innovation as any form of innovation that results or seeks meaningful progress and demonstrable to achieving sustainable development, by reducing impacts on the environment, improving resilience to environmental pressures, or making more efficient and responsible use of natural resources (ASEI | ASEM Eco-Innovation Index, 2016).

The Organization for Economic Cooperation and Development (OECD) defined eco-innovation as the development of products (goods and services), processes, marketing methods, organizational structure and new or improved institutional arrangements that, intentionally or not, contribute to reducing environmental impact, when compared to alternative practices (OECD, 2009).

However, Kemp and Foxon (2007) defined eco-innovation as the production, assimilation or exploitation of a novelty in products, processes, services or management methods, which aim, throughout their life cycle, to prevent or reduce substantially Environmental risk, pollution and other negative impacts on the use of resources.

Thus, the various definitions of eco-innovation converge in the same direction and agree that it produces positive synergistic effects on the economic, social and environmental conditions of a society, and consequently of its country. This concept has been adopted in international organizations, research institutes and universities that emphasize the importance of eco-innovation as an enabler of sustainable deve- 
lopment (OECD, 2011). Figure 1 presents a vision that helps demonstrate the importance of eco-innovation. It is important for creating economic and environmental value in three perspectives: (i) Micro: Company; (ii) Meso: Sector, and; (iii) Macro: Country. Thus, eco-innovation enables the enhancing countrys's competitiveness, valuing the triple bottom line.

Figure 1 - Why do we need Eco-Innovation?

<Creating Economic and Environmental Value> <Enhancing Country's Competitiveness>

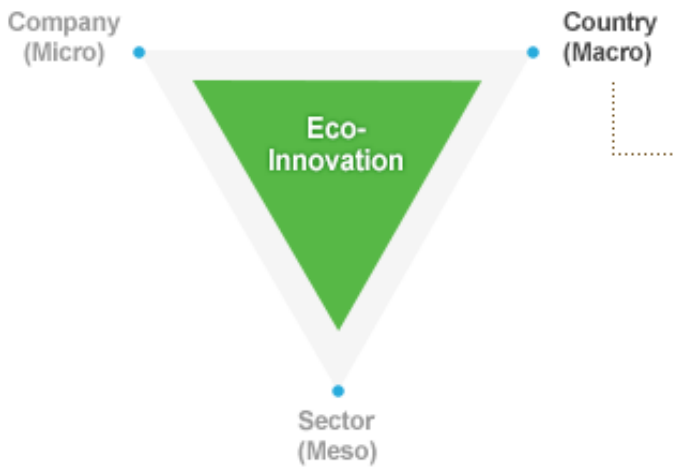

Source: ASEI | ASEM Eco-Innovation Index, 2016

Next, this paper presents a literature review on the context in which ecoinnovation is inserted. This context focuses on the relationship evolution between society, business and eco-innovation itself.

\section{CONTEXTUALIZING ECO-INNOVATION}

Cantwell and Mudambi (2011) highlighted that multinationals, organizational entities with subsidiaries scattered around the world, use innovation to create new markets and to mitigate threats, from their rivals in a marketplace highly complex, uncertain and globally competitive.

In addition, some papers such as Spaargaren and Oosterveer (2010) and Verbeke et al. (2010), added to the previous concept that, innovation in companies seeks to exploit technological and market opportunities, responding to changes in consumer demand and lifestyle.

In this sense, Bocken et al. (2011) pointed out that green consumer awareness, social pressure and government policies to reduce negative environmental im- 
pact have grown. Analyzing the changing behavior of society, in which it involves the growth of its conscience by the sustainability, the companies have been preoccupied in the adoption of technological advances that consider social and environmental questions.

Confirming this concern, Dangelico and Pujari (2010) stated that the innovation used to develop sustainable products has been recognized as one of the main factors to achieve growth, environmental sustainability and a better life quality. Understanding green product innovation as a result of the interaction between innovation and sustainability, has become a strategic priority for theory and practice.

In this way, it can be said that the expansion of society's awareness has led to rise of sustainability topic in its environmental dimension and of innovation topic as a means of mitigating environmental problems resulting from economic development, promoting the formation, development and use of new technologies to the world. In addition to these two topics, comes up environmental innovation concept, also called eco-innovation, sustainable innovation, or green innovation (BOONS; LUDEKEFREUND, 2013, FAGERBERG 2005, SANTOLARIA et al., 2011).

Hellstrom (2007), evaluating eco-innovation design, emphasized that it considers the social, economic and environmental dimensions (triple bottom line) for its adoption and implementation. Eco-innovation influences organizational and consumer practices, based on the basic principle of reduction in environmental impact, seeking positive exchanges between environmental attributes and critical success factors in development of products and processes.

As a threat to this new way of thinking that would consequently affect consumption, Porter and Van Der Linde (1995), and Andersen (2004) already emphasized the traditional and conservative view of the business world, by which companies visualized an environmental strategy as contrary to its objectives of growth, competitiveness and profitability. These authors defended the possibility of company to grow, being sustainable.

In this direction, Korhonen (2001) warned that innovation and sustainability became central concepts for any industrial or commercial activity and should be well assimilated by the companies management to coordinate their activities.

Andersen (2008) pointed out that environmental innovation topic was still little explored in industry operations. According to this author, the reason for this is that 
industrial dynamics was still usually motivated by profitability, according to the assumptions of neoclassical economics. In order for there, to be synergy between environmental innovation and industry, this author defended a new approach to understanding the environmental issue and adoption of technology, considering industry as an innovative actor and not only a simple polluter.

In this new approach for the synergy between environmental innovation and industry, Baumgartner and Ebner (2010) argued that companies were increasing the adoption of sustainability practices, although it was not yet clear if these companies were to adopt these practices strategically or unintentionally.

Researching on the formation of eco-innovation concept in companies, Bossle et al. (2015) stated that, considering that the OECD concept is not restricted to the intentionality of environmental improvement, it is of great importance to verify what are the guidelines and motivations that lead companies to adopt environmental precepts. For although issues such as innovation and sustainability are the most common topics in both academic and practical debate, there is not still clarity about what companies are actually doing and how they are integrating these concepts into their activities and strategies.

According to this principle, Morgadinho et al. (2015) analyzed the perceptions of main stakeholders of European car manufacturers (oil, tires, electric batteries and IT industries) and universities on eco-innovation. They found that both stakeholders and universities were conducting research on technologies to reduce greenhouse gas emissions from passenger cars. They conclude that there is strong interest of the automotive sector and associated industries in technologies to reduce pollutant emissions. These authors pointed out that, for this, there is a need for political decisions on sustainable mobility and behavioral change in society.

Regarding policy decisions to favor the development of eco-innovation, Doran and Ryan (2016) highlighted that government regulations and subsidies oriented to industry play a key role as a success factor for encouragement of formation, development and use of eco-innovation and for corporate performance, in any government, from any country of the world. 


\section{METHODOLOGY}

This work was exploratory character, with literature review. A research focused on a specific theme (eco-innovation), with a structure directed by keywords, was carried out in international research bases.

The research was initiated by the search of articles published between 2011 and 2015, which contained Eco-Innovation or Environmental Innovation expression, in any of its parts (title, abstract, keywords). There were thus found 8,379 articles. This research reveals that during the period evaluated, the topic in question maintained a steady growth of publications and almost doubled its number in five years, as can be seen in Figure 2.

Figure 2 - Evolution of publications with the topic "Eco-Innovation" or "Environmental Innovation"

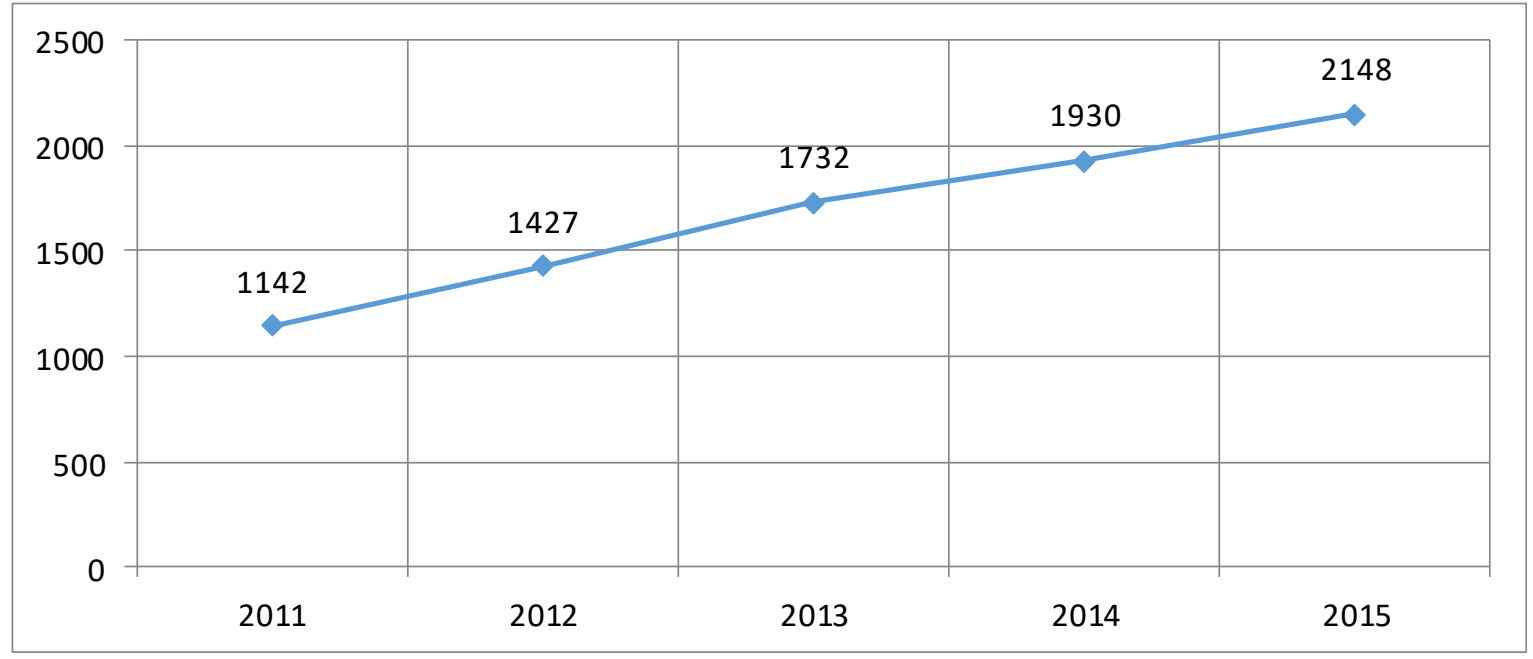

Source: Prepared by the authors

The criterion for choosing the analyzed articles began by filtering the keywords most cited in the 8,379 articles found. Table 1 highlights the top twenty keywords found and the number of articles in which they are found, in descending order. From the main keywords found by the research, the most remarkable are the keywords "Eco-Innovation" or "Environmental Innovation", cited respectively in 124 and 72 articles, of the 8,379 found in the initial phase of the research, that is, corresponds to $1,5 \%$ and $0,9 \%$ of the articles, respectivelly.

Subsequently, no restrictions were imposed with respect to authors, institutions or any other delimiter, in addition to those already predetermined and presented 
by the research. In this way, a wide evaluation was allowed from different angles regarding the articles that included as keywords "Eco-Innovation" and "Eco-Innovation".

However, not all the articles that contained those keywords were analyzed. The ten most cited articles were selected for analysis, within the selection criteria already highlighted. Also considered in this analysis was the level of periodical qualification in which article was published, by international citation standards.

Table 1 - Main keywords of articles with the topic "Eco-Innovation" or "Environmental Innovation"

\begin{tabular}{lcc}
\hline Keywords & Quantity & Percentage (\%) \\
\hline Innovations & 1.764 & 21.1 \\
Issues in Sustainable De- & 1.736 & 20.7 \\
Studies & 1.616 & 19.2 \\
Economics & 1.422 & 17,0 \\
Innovation & 1.109 & 13.2 \\
Experiment/Theoretical Tre- & 936 & 11.1 \\
Sustainable Development & 825 & 9.8 \\
Technology & 760 & 9.1 \\
Environmental Policy & 749 & 8.9 \\
Pollution Control & 736 & 8.8 \\
Sustainability & 657 & 7.8 \\
Energy & 655 & 7.8 \\
Experimental/Theoretical & 599 & 7.1 \\
Climate Change & 390 & 4.7 \\
Technological Change & 384 & 4.6 \\
Western Europe & 379 & 4.5 \\
China & 343 & 4.1 \\
Environmental Management & 303 & 3.6 \\
Eco-Innovation & 124 & 1.5 \\
Environmental Innovation & 72 & 0.9
\end{tabular}

Source: Prepared by the authors

The analysis process of ten most relevant articles was done initially based on evaluation of the title, abstract and keywords. Table 2 identifies the ten articles selected and analyzed on the topics and established criteria, their keywords and the periodical where they were published. This table also highlights the importance and contribution of the Journal of Cleaner Production in relation to research subject, publishing eight of the ten articles analyzed.

Analyzing Table 2, it can be observed that in the ten articles presented, thirtynine (39) keywords are highlighted, with the keyword Eco-innovation appearing in all ten articles listed. In addition to this analysis, it is confirmed that only two other 
keywords appear repeated: (i) Drivers (2 times) and (ii) Eco-design (2 times). It should also be emphasized that some of the words involved in this context deserve to be highlighted for their importance in connection with the subject: Environmental, Sustainability, Innovation, Management, Transport and Material Selection.

Table 2 - The 10 most relevant articles selected

Articles
1. The drivers for adoption of
eco-innovation
2. The "economic-finance in-
terface" for eco-innovation
projects

5. The relativity of ecoinnovation: environmental rebound effects from past transport innovations in Europe

6. IT for green and green IT: A proposed typology of ecoinnovation

7. Material selection for ecoinnovation: SPICE model

8. A comprehensive review of the evolving and cumulative nature of eco-innovation in the chemical industry

9. Process eco-innovation: assessing meso-level ecoefficiency in industrial waterservice systems

10. Accelerating preliminary eco-innovation design for products that integrates case-based reasoning and TRIZ method

$$
\begin{gathered}
\text { Keywords } \\
\text { Eco-innovation; Environmental } \\
\text { sustainability; Systematic review; } \\
\text { Adoption of environmental } \\
\text { innovation; Drivers; Companies } \\
\text { Eco-innovation; Project } \\
\text { management; Corporate finance } \\
\text { Eco-innovation } \\
\text { Drivers; Integrative capability; } \\
\text { Performance } \\
\text { Eco-innovation; Green } \\
\text { innovation; Sustainability; } \\
\text { Environmental management }
\end{gathered}
$$

Rebound effect; Eco-innovation; Transport innovation; Sustainable transport; Life cycle assessment;

$$
\text { Europe }
$$

IT; Ecological economics; Ecoinnovation; Externalities;

Business ecosystem; Collective innovation; Smart grid

Ecodesign; Eco-innovation;

Material selection; Stakeholders; Trade-offs

Eco-innovation; Environmental innovation; Chemical industry;

Sustainability transitions; Environmental change

Eco-efficiency; Meso level (whole system); Eco-innovation; Value chain; Volvo Trucks; Arla Foods

Case-based reasoning; TRIZ; Eco-innovation; Eco-design
Journal

Journal of

Cleaner

Production

International

Journal of Project

Management

Journal of

Cleaner

Production

Journal of

Cleaner

Production

Journal of

Cleaner

Production

Ecological

Economics

Journal of

Cleaner

Production

Journal of

Cleaner

Production

Journal of

Cleaner

Production

Journal of

Cleaner

Production

Source: Prepared by the authors 
In relation to the place (universities) where the researches of the ten listed articles were carried out, it can be seen that the theme in question, analyzed by this study, is being worked on several fronts, since 14 different countries were referenced: Brazil, China, Denmark, England, France, Greece, Mexico, Netherlands, South Africa, Spain, Sweden, Taiwan, United States of America and Wales.

Five of the fourteen countries had universities that published in two different articles, out of the ten selected ones. They were: England, France, Holland, Taiwan and Wales. In addition, it is also noticed that some researchers, from different countries, in search of development on the subject, are coming together for the research and publication. Of the ten articles selected, four were carried out by this practice.

\section{OUTLOOK AND ANALYSIS ABOUT RECENTLY PUBLISHED ARTICLES}

Considering the literature review and the ten articles analysis, it was possible to elaborate a framework on eco-innovation, represented by Figure 3.

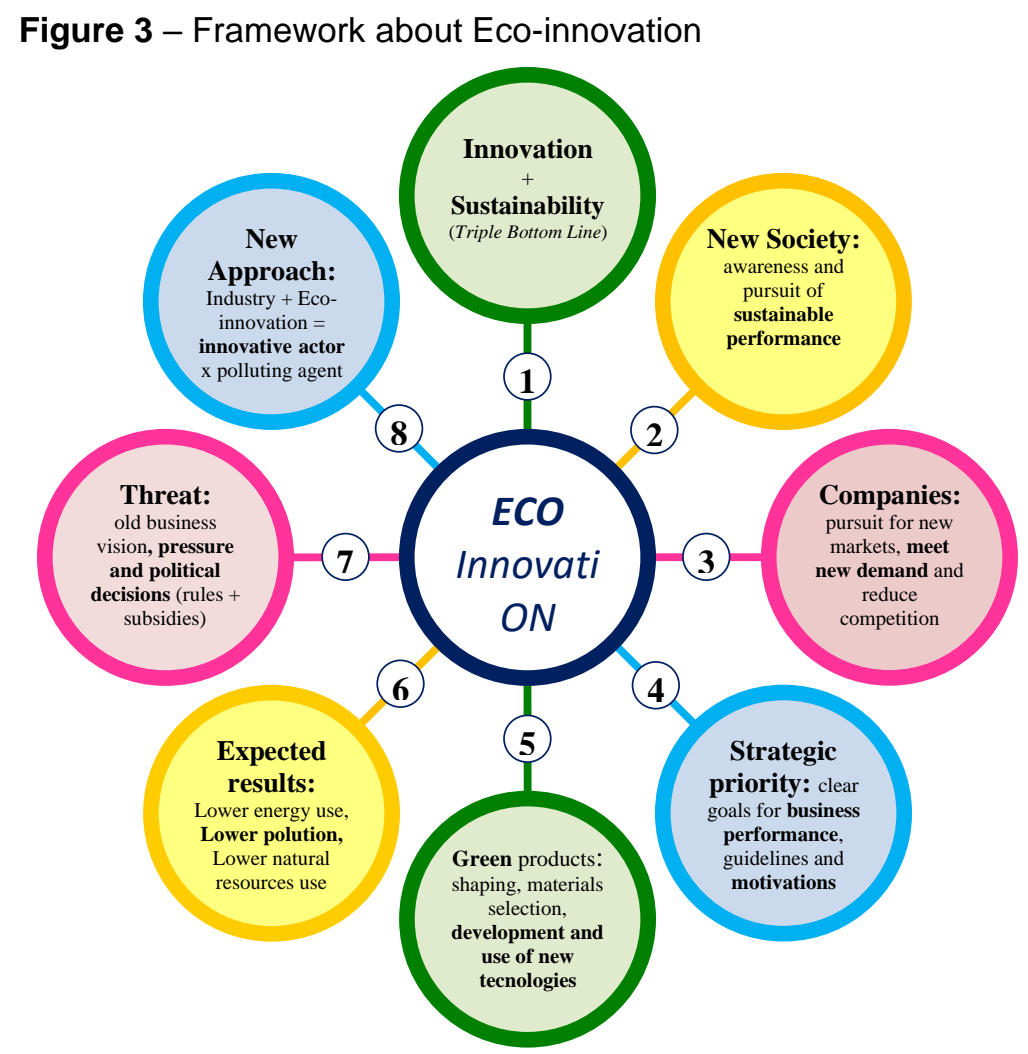

Source: Prepared by the authors

Article 1: Bossle et al. (2015) highlighted and considered the importance of understanding why and how companies integrate the concept of sustainability into 
the innovation process. In this sense, the article presents some questions: (i) How does the business literature relate eco-innovation to the guidelines that drive the adoption of the same by companies? (ii) What are the guidelines and motivations for adopting eco-innovations by companies? (iii) How could results found in the literature help to define a conceptual framework for eco-innovation guidelines and motivations?

The results found for the questions indicated that there is a growing interest in this concept, not only from an industry, but also from the academic point of view, evidenced by ongoing research and publications. These evidences show that the main eco-innovative companies are protagonists in the development of new technologies; But in some cases, to drive the focus on eco-innovation, companies need to define it as an explicit goal in their strategy.

The article 1 have strong connection with Figure 3 links (mainly 1, 4, 5).

Article 2: Scarpellini et al. (2016) emphasized that eco-innovation is widely accepted as a viable direction for sustainable development. However, the authors pointed out that in many European countries, eco-innovation projects were not as common until the date of research. The article also highlighted that eco-innovation should offer a new strategic approach to the industry, with regard to the management of sustainable and innovative initiatives.

The paper analyzed forty-four eco-innovation projects applied in industry, with the objective of defining an "economic-financial interface" for eco-innovation projects. The analysis of selected companies highlighted that eco-innovative investments were implemented in all sectors. However, the manufacturing sector had projects selected most often. Another very important result presented by the work was a guidance manual on the implementation of eco-innovation, to align project management of this theme with the business strategy that a company intends to adopt.

The work also presented main characteristics of the companies with ecoinnovations applied. Of these characteristics, the following should be highlighted: (i) most companies with more than 250 employees (39\%); (ii) majority of companies over 40 years of age (36\%); (iii) the main strategies applied were cost optimization and reduction of environmental impact (44\%); (iv) most projects have medium or long term (75\%), and; (v) short-term projects are linked to lower investment projects, as long-term projects are linked to higher investment projects.

The article 2 have strong connection with Figure 3 links (mainly 4, 6, 8). 
Article 3: Cai e Zhou (2014) emphasized that identification of eco-innovation guidelines in companies is a popular topic in the literature, but many questions about these guidelines in developing countries remain unanswered. The study aimed to verify empirically main factors that influence adoption of eco-innovation in Chinese companies. To achieve this, a conceptual model has been developed and tested in the industry. This model was formed by the following variables: (i) internal guidelines; (ii) external guidelines; (iii) integration capacity; (iv) eco-innovative performance, and; (v) external relationship strength.

The study revealed that external guidelines affect eco-innovation through internal guidelines. Internal guidelines act as a bridge between external guidelines and integration capacity. The capacity for integration can effectively facilitate the performance of eco-innovation and should be treated with importance. The external relationship strength acts as a moderator between external guidelines and integration capacity.

However, the authors argued that the most eco-innovative Chinese companies are those that need to deal with a demand for external pressures (international), which involve environmental regulations for the marketing of products (exports). Thus, the authors concluded that companies that have exports tend to carry out more eco-innovative activities. In addition, they commented that this study contributes to a more detailed understanding of factors that initiate and drive eco-innovation in China.

The article 3 have strong connection with Figure 3 links (mainly 2, 3, 7).

Article 4: Cheng et al. (2014) remember that in practice there are various ecoinnovation types, and while each type of innovation has its own attributes and contribution to business performance, it is not effective to implement eco-innovation programs without a holistic view on the subject. This study used Resource-Based View (VBR) to investigate the interrelationships between three eco-innovation types (process, product, organizational) and their impacts on business performance.

The study revealed that organizational eco-innovation is one that has the strongest effect on business performance. However, eco-innovations in products and processes contribute to the effects of organizational eco-innovation and product ecoinnovation mediate the effects of process eco-innovations on business performance. In this sense, the authors stated that business performance is affected directly and indirectly by all eco-innovation types and suggested that, in order to develop effective 
eco-innovation programs, industrial managers should study and deepen their understanding among eco-innovation different types.

The article 4 have strong connection with Figure 3 links (mainly 3, 4, 8).

Article 5: Vivanco et al. (2015) remenbered that eco-innovation topic has been coined to label innovations intended to reduce environmental impacts and burdens. Thus, claims for environmental improvements are often supported by technology-driven analyzes. However, this depends not only on their technical characteristics, but also on interactions between technology development and demand.

In this paper, the authors incorporate such interactions into the concept of "environmental rebound effect", which in transport context, can be defined as a change in transport demand caused by a technical change in its system (eg, more fuelefficient vehicle). However, magnitude of this effect must be correlated with two variables: total change in effective income resulting from the use of innovation, and difference between value of innovations studied by environmental pressures and value of innovations used for common consumption.

Seven eco-innovations for European transport were analyzed by the work: (i) Catalytic converters in passenger cars; (ii) Diesel engine in passenger cars; (iii) Direct fuel injection systems in passenger cars; (iv) High speed rail; (v) Park-and-ride facilities; (vi) Car sharing schemes, and; (vii) Bicycle sharing systems. However, only three of the seven eco-innovations studied, with environmental improvements, would be supported in their real economic functioning (i, iii and $v$ ).

The article 5 have strong connection with Figure 3 links (mainly 4, 5, 6).

Article 6: Faucheux e Nicolaï (2011) discussed from an interdisciplinary perspective, the increasing use of IT (Information Technology) and its applications for benefit of the environment (green IT). They commented that IT and sustainable development have seen a concomitant increase in recent years and both can come together to offer future world an alternative to current and questionable model of industrial development.

In its first part, this paper analyzed the economic, social and environmental impact that IT promotes, finding the need for adjustments, in search of sustainable results. In the second part, the article focused on the gerecial dimension of ecoinnovation and presented one of the differentials of the green IT: the collective organization of innovation. 
The authors, based on survey results, concluded that there should be an adjustment between eco-innovation types and green IT development. This adjustment should explicitly address four types of change for sustainable development: technological, social, institutional and organizational innovation.

The article 6 have strong connection with Figure 3 links (mainly 1, 2, 5).

Article 7: Prendeville et al. (2014) highlighted that realization of a sustainable society requires eco-innovation designers, with materials selection that will compose the product. They comment that resource-oriented features are evolving, with physical materials libraries, databases, software and tools that connect materials with designers. However, materials selection needs a broader consideration system, reflecting sectoral behavior, stakeholders, legislation, access to knowledge and networks involved with the product being developed. The objective of this article was to deepen the understanding of eco-design, investigating role of key stakeholders during materials selection for eco-innovative products development.

The method used in the research was the in-depth case study, in a furniture design business, with a focus on sustainability. Four case studies have been incorporated into the development of new products. Interviews, visits and observation of activities were used for this research, during three years. The article presented a comparison between eco-innovations based on new material adoptions with materials normally used by the furniture industry. The authors stated that ecodesign strategies included: (i) Design for disassembly, (ii) Dematerialization, (iii) Materials simplification, and (iv) Parts reduction.

The results found by work highlighted how the effectiveness of eco-design in decision making is strongly dependent on stakeholders knowledge. Finally, paper presents a new conceptual model for materials classification. Thus, the authors concluded that the model presented helps in strategic design management and materials selection for eco-innovation.

The article 7 have strong connection with Figure 3 links (mainly 2, 5, 6).

Article 8: Díaz López e Montalvo (2015) analyzed the sustainability transitions, providing an account of chemical industry evolution to the design, use and production of chemicals products environmentally friendly with eco-innovation-based processes and products. A conceptual model was elaborated describing five stages of environmental change in chemical industry between 1901 and 2030. The authors 
empirically test this model, addressing different environmental and innovation aspects in this industry during the same period of time.

The conclusions of this article highlighted an accumulated number of factors that allowed the evolution of chemical industry work with eco-innovation. Among the factors were environmental regulations, chemical industry's vocation for innovation and the technological changes that occurred in period evaluated. Thus, the authors finalized the article stating that the future development of this industry should be shaped by paradigms of political guidelines of sustainability and efficiency in resources use.

The article 8 have strong connection with Figure 3 links (mainly 4, 7, 8).

Article 9: Levidow et al. (2016) commented that eco-innovation should combine economic advantages with lower burdens on ecological resources. Thus, ecoinnovation has been oriented to alternatives in energy production, components recycling, etc. In this sense, the work investigated options for eco-efficiency improvement in two large manufacturing companies, Volvo and Arla Foods.

The authors claim that the stimulus for eco-innovation of these companies comes from internal environmental policies as well as from external factors such as higher future costs and resources scarcity. In relation to their respective industrial sectors, these companies represent strong prospects for a reduction in resources use in water supply processes, especially from chemical inputs and waste. In addition, Volvo also has eco-innovations geared towards fuel efficiency, while Arla Foods has eco-innovations geared towards $\mathrm{CO} 2$ reductions from renewable energy sources or more efficient transport.

The article defines as objective the development of a project called EcoWater. This project analyzed entire value chain in water supply, through interactions between stakeholders (users, suppliers and treatment companies). The project developed a methodology for obtaining necessary information, involving stakeholders and facilitating their discussion on alternative options. With the results, authors concluded that project helped companies studied to seek greater efficiency in water use and wastewater treatment. In addition, when comparing options, the method can facilitate decisions by resource efficiency improvement.

The article 9 have strong connection with Figure 3 links (mainly 5, 6, 8). 
Article 10: Yang e Chen (2011) reported that while innovation capacity and market potential of a new product is usually emphasized, its environmental impact is often neglected to address issues such as performance, cost and durability. Despite its ability to help designers reduce products environmental impact throughout life cycle, many eco-design methods focus on redesigning existing products and neglect to evaluate the possibility of using new materials.

This paper describes and evaluated a new model to accelerate the preliminary design of eco-innovative products, integrating the advantages of case-based thinking with the inventive solution to problems (CBR and TRIZ methods). The model was developed in accordance with the guidelines of the World Business Council for Sustainable Development (WBCSD), aimed at redesigning the functional performance of eco-innovation.

The authors concluded that the proposed model may help new products to be more eco-innovative. In this sense, four eco-innovative concepts for a PC mouse were presented, demonstrating the effectiveness of the model proposed in practice.

The article 10 have strong connection with Figure 3 links (mainly 4, 5, 6).

\section{CONCLUSION}

It is important to emphasize, before research carried out, there is a great, consistent and growing interest by companies and universities on Eco-innovation theme. The studies analyzed point out that companies and universities have studied, mainly, the factors that drive eco-innovation (motivations) and projects that combine economic advantages for companies with a lower environmental impact to society (directives).

The research also points to the consensus among companies and universities that eco-innovation is a viable direction, as progress towards sustainable development and as a response for companies, linking innovation to sustainability. However, it is clear from the results presented by some companies studied, that will be successful only those companies that have eco-innovation as an explicit goal in their strategy.

Regarding the guidelines that lead to eco-innovation, the research concludes that, in companies eco-innovation can be triggered by internal and external guideli- 
nes. As good examples, it is possible to indicate as internal guideline, the stimulus that some companies promote for the eco-innovations development by their own environmental policies, while as an external guideline, can be emphasized the demand, green awareness, resources scarcity, higher costs and pressures for environmental policies.

Three types of eco-innovation were identified: oriented to process, product and organization. However, the research carried out finds in the organizational ecoinnovations a greater effect on the performance of the business, in its technicalfinancial viability character. Product and process eco-innovations also play an important and complementary role in organizational eco-innovations.

Many authors describe that eco-innovation term has emerged to label innovations intended to reduce environmental burdens. They also cite that new technologies help in this process, but it depends on demand to come true. They also point out that when there is no demand, public policies and government incentives should help industries develop and sell eco-efficient products. In this way, an economically unviable green demand would not be practiced as a consequence of environmental pressures.

It may also be pointed out the need for investment in research for development of new eco-friendly materials. These materials can replace harmful materials to environment, allowing to improve the product life cycle and reduce its environmental impact. It should be noted that these issues have been neglected by innovation capacity or market potential. For this, legislation, access to knowledge and information technology can contribute to selection of correct materials and to evolution of the collective organization of this innovation.

It is concluded that eco-innovation can provide economic benefits by reducing environmental impact. This can be achieved through technological innovations aimed at reducing energy consumption, reducing natural resources use, recycling components and reducing the emission of pollutants.

One sector worth mentioning in these initiatives is the transportation sector. Through incentives, environmental standards and automotive industry innovation, there is a work to reduce environmental impact, especially as regards the reduction in consumption of non-renewable resources (oil, other sources of energy and water), with alternatives fuel development, for a lower pollutants emission, such as CO2. 
Finally, this paper concludes that eco-innovations must first of all be financially viable for the industry, having its guidelines aimed at the business performance and motivated by the knowledge that the managers involved in the project should have about the company with its vision based and focused on available resources.

\section{REFERENCES}

ANDERSEN, M.M.An innovation system approach to eco-innovation e aligning policy rationales. In: GREENING OF POLICIESDINTERLINKAGES AND POLICY INTEGRATION CONFERENCE. [Proceedings...]. Berlin, Germany, 3 December, 2004.

ANDERSEN, M.M. Econ-Innovation: towards a taxonomy and a theory. Paper to be presented at the 25th Celebration Conference 2008 on Entrepreneurship and Innovation - Organizations, Institutions, Systems and Regions. Copenhagen, CBS, Denmark, June 17-20, 2008.

ASEI | ASEM Eco-Innovation Index. Measuring sustainable future for asia and Europe. Disponível em: http://www.aseic.org/aeii/OverviewR.do. Acesso em: 15 de maio 2016.

BAUMGARTNER, R.J., EBNER, D. Corporate sustainability strategies: sustainability profits les and maturity levels. Sustain. Dev. v.18, p. 76-89, 2010.https://doi.org/10.1002/sd.447

BOCKEN, N.M.P.; ALLWOOD, J.M.; WILLEY, A.R. ; KING, J.M.H. Development of an ecoideation tool to identify stepwise greenhouse gas emission reduction options for consumer goods. J. Clean. Prod. v. 19, p. 1279-1287, 2011. https://doi.org/10.1016/.j.jclepro.2011.04.009

BOONS, F. ; LÜDEKE-FREUND, F. Business models for sustainable innovation: state-ofthe-art and steps towards a research agenda. J. Clean. Prod. v. 45, p. 9-19, 2013. https://doi.org/10.1016/i.jclepro.2012.07.007

BOSSLE, M.B.; BARCELLOS, M.D.; VIEIRA, L.M.The drivers for adoption of eco-innovation. J. Clean. Prod. v. 113, p. 861-872, 2015. https://doi.org/10.1016/.j.clepro.2015.11.033

CAI, W.; ZHOU, X. On the drivers of eco-innovation: empirical evidence from China. Journal of Cleaner Production, v. 79, p. 239-248, 2014.

https://doi.org/10.1016/j.jclepro.2014.05.035

CANTWELL, J.; MUDAMBI, R. Physical attraction and geography of knowledge sourcing in multinational enterprises. Global Strategy Journal, v. 1, n.3/4, p. 206-232, 2011. https://doi.org/10.1002/gsi.24

CHENG, C.C.J., YANG, C., SHEU, C.The link between eco-innovation and business performance: a Taiwanese industry context. Journal of Cleaner Production, v. 64, p. 81-90, 2014. https://doi.org/10.1016/i.jclepro.2013.09.050

DANGELICO, R.M.; PUJARI, D. Mainstreaming green product innovation: why and how companies integrate environmental sustainability. J. Bus. Ethics, v. 95, p. 471-486, 2010. https://doi.org/10.1007/s10551-010-0434-0 
DÍAZ LÓPEZ, F.J.; MONTALVO, C. A comprehensive review of the evolving and cumulative nature of eco-innovation in the chemical industry. Journal of Cleaner Production, v. 102, p. 30-43, 2015. https://doi.org/10.1016/j.jclepro.2015.04.007

DORAN, J.; RYAN, G.The importance of the diverse drivers and types of environmental innovation for firm performance. Bus. Strat. Env. v. 25, 102-119, 2016.

https://doi.org/10.1002/bse.1860

FAGERBERG, J. Innovation: a guide to the literature. In: FAGERBERG, J.; MOWERY, D.; NELSON, R. (Eds.). The oxford handbook of innovation. Oxford: Oxford University Press, p. 1-27, 2005. https://doi.org/10.1093/oxfordhb/9780199286805.001.0001

FAUCHEUX, S.; NICOLAÏ, I.IT for green and green IT: A proposed typology of ecoinnovation. Ecological Economics, v. 70, p. 2020-2027, 2011.

https://doi.org/10.1016/j.ecolecon.2011.05.019

HELLSTROM, T. Dimensions of environmentally sustainable innovation: the structure of ecoinnovation concepts. Sustain. Dev. v.15, n.3, p. 148-159, 2007. https://doi.org/10.1002/sd.309

KEMP, R.; FOXON, T. J. Tipology of eco-inovation. In: MEI project: measuring EcoInovation. European Commission, ago. 2007.

KORHONEN, J.Four ecosystem principles for an industrial ecosystem. J. Clean. Prod. v. 9, p. 253- 259, 2001. https://doi.org/10.1016/S0959-6526(00)00058-5

LEVIDOW, L.; LINDGAARD-JØRGENSEN, P.; NILSSON, A.; SKENHALL, S.A.; ASSIMACOPOULOS, D. Process eco-innovation: assessing meso-level eco-efficiency in industrial water-service systems. Journal of Cleaner Production, v. 110, p. 54-65, 2016.

https://doi.org/10.1016/j.jclepro.2014.12.086

MORGADINHO, L; OLIVEIRA, C; MARTINHO, A. A qualitative study about perceptions of European automotive sector's contribution to lower greenhouse gas emissions. Journal of Cleaner Production, v.106, n. 1, p. 644-653, nov. 2015. https://doi.org/10.1016/i.jclepro.2015.01.096

OECD - The Organisation for Economic Co-operation and Development. Sustainable manufacturing and eco-innovation: towards a green economy. Policy Brief, 2009.

OECD - The Organisation for Economic Co-operation and Development. The future of ecoinnovation: the role of business models in green transformation, 2011.

PORTER, M.E.; VAN DER LINDE, C.Green and competitive: ending the stalemate. Harv. Bus. Rev, p. 120-133, September-October, 1995.

PRENDEVILLE, S.; O'CONNOR, F.; PALMER, L. Material selection for eco-innovation: SPICE model. Journal of Cleaner Production, v. 85, p. 31-40, 2014. https://doi.org/10.1016/j.jclepro.2014.05.023

SANTOLARIA, M.; OLIVER-SOL, A, J.; GASOL, C.M.; MORALES-PINZON, T.; RIERADEVALL, J. Eco-design in innovation driven companies: perception, predictions and the main drivers of integration. The Spanish example. J. Clean. Prod. v.19, p. 1315-1323, 2011. https://doi.org/10.1016/j.jclepro.2011.03.009 
SCARPELLINI, S., VALERO-GIL, J., PORTILLO-TARRAGONA, P., 2016. The economicfinance interface for eco-innovation projects. International Journal of Project Management, v. 34, p. 1012-1025. https://doi.org/10.1016/j.ijproman.2016.04.005

SPAARGAREN, G., OOSTERVEER, P.Citizen-consumers as agents of change in globalizing modernity: the case of sustainable consumption. Sustainability, v. 2, n. 7, p. 1887-1908, 2010. https://doi.org/10.3390/su2071887

VERBEKE, W.; PÉREZ-CUETO, F.J.; DE BARCELLOS, M.D.; KRYSTALLIS, A.; GRUNERT, K.G. European citizen and consumer attitudes and preferences regarding beef and pork. Meat Sci, v. 84, n. 2, p. 284-292, 2010. https://doi.org/10.1016/i.meatsci.2009.05.001

VERGHESE, K., LEWIS, H. Environmental innovation in industrial packaging: a supply chain approach. Int. J. Prod. Res. v. 45, n. 18-19, p. 4381-4401, 2007. https://doi.org/10.1080/00207540701450211

VIVANCO, D.F.; KEMP, R.; VOET, E. The relativity of eco-innovation: environmental rebound effects from past transport innovations in Europe. Journal of Cleaner Production v.101, p. 71-85, 2015. https://doi.org/10.1016/j.jclepro.2015.04.019

YANG, C.J.; CHEN, J.L.Accelerating preliminary eco-innovation design for products that integrates case-based reasoning and TRIZ method. Journal of Cleaner Production, v.19, p. 998-1006, 2011. https://doi.org/10.1016/j.jclepro.2011.01.014

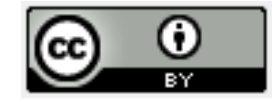

Artigo recebido em: 29/10/2018 e aceito para publicação em: 14/09/2020

DOI: $\underline{10.14488 / 1676-1901 . v 20 i 3.3423}$ 